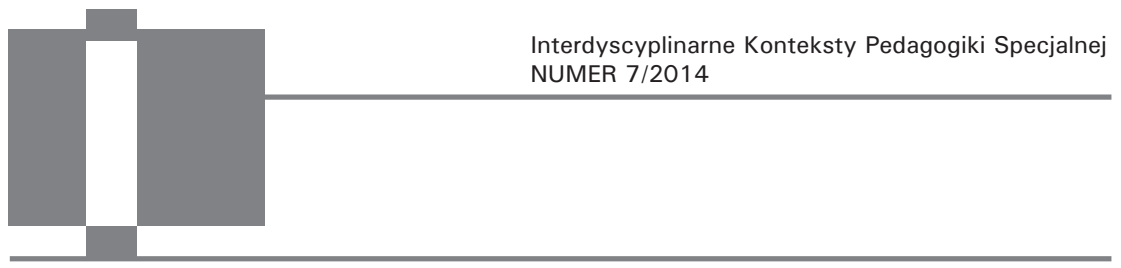

\title{
Sprawozdanie z XIII Konferencji Naukowej z cyklu Dyskursy Pedagogiki Specjalnej, „Pozainstytucjonalna przestrzeń życia osób niepełnosprawnych" (Gdańsk, 13-15 maja 2015 r.)
}

W dniach 13-15 maja 2015 r. w Gdańsku odbyła się XIII Konferencja Naukowa z cyklu Dyskursy Pedagogiki Specjalnej, która już na dobre wpisała się w krajobraz naukowych spotkań pedagogów specjalnych w naszym kraju. Dyskursy zapoczątkowane zostały w 2001 r. przez zespół pracowników Uniwersytetu Warmińsko-Mazurskiego pod przewodnictwem prof. Czesława Kosakowskiego. Do 2011 r. zaowocowały one dziesięcioma wydaniami naukowych prac zbiorowych pod tym samym tytułem. Konferencja od kilku lat organizowana jest na Uniwersytecie Gdańskim pod kierunkiem prof. dr. hab. Amadeusza Krause i tam kontynuowana jest tradycja cyklicznych debat naukowców, które publikowane są w periodyku „Niepełnosprawność. Dyskursy Pedagogiki Specjalnej". Tym razem XIII Dyskursy Pedagogiki Specjalnej pt. „Pozainstytucjonalna przestrzeń życia osób niepełnosprawnych" zgromadziły ponad osiemdziesięciu przedstawicieli ośrodków uniwersyteckich, naukowych i praktyków pedagogiki specjalnej z całej Polski.

Konferencję otworzyły pani Dziekan Wydziału Nauk Społecznych Uniwersytetu Gdańskiego prof. dr hab. Beata Pastwa-Wojciechowska oraz pani Dyrektor Instytutu Pedagogiki dr hab. Sławomira Sadowska. Pierwszy dzień obrad poprowadził Kierownik Zakładu Pedagogiki Specjalnej UG prof. dr hab. Amadeusz Krause. Konferencja rozpoczęła się sesją plenarną, na której odbyły się dwie debaty: debata profesorska i debata doktorska. 
Debata profesorska skupiła się wokół dwóch ważnych tematów w pedagogice specjalnej: inkluzji oraz standardów kształcenia pedagogów specjalnych. Zaproszeni do niej zostali: prof. dr hab. Iwona Chrzanowska (UAM Poznań), dr hab. Grażyna Dryżałowska (prof. UW, Warszawa), prof. dr hab. Zenon Gajdzica (UŚ Katowice), dr hab. Beata Jachimczak (prof. UAM, Poznań), dr hab. Zdzisława Janiszewska-Nieścioruk (prof. UZ, Zielona Góra), dr hab. Sławomir Przybyliński (prof. UWM, Olsztyn), dr hab. Sławomira Sadowska (UG Gdańsk), dr hab. Grzegorz Szumski (prof. APS, Warszawa), prof. dr hab. Marzena Zaorska (UWM Olsztyn).

Wśród zgromadzonych profesorów dominował pogląd o słuszności etycznej edukacji inkluzyjnej, lecz wskazali oni na problemy, jakie wiążą się z jej realizacją. W wielu wypowiedziach uczestników debaty pojawiły się dylematy dotyczące możliwości wyboru rodzaju edukacji. Dr hab. Sławomira Sadowska zauważyła, że pewne grupy osób z niepełnosprawnością wybierają inkluzję, a inne edukację specjalną. Badania jakości życia osób z niepełnosprawnością pokazują, że mimo iż segregacja jest źle postrzegana społecznie, to środowisko szkoły specjalnej daje większe zadowolenie uczniom niepełnosprawnym i ich rodzinom w porównaniu $\mathrm{z}$ innymi szkołami. Prof. dr hab. Amadeusz Krause podkreślił, że Konwencja o Prawach Osób Niepełnosprawnych, ratyfikowana przez Polskę w 2012 r., mówi o tym, że osoby niepełnosprawne mają korzystać z włączającego, obowiązkowego nauczania, i nie daje w tej kwestii możliwości wyboru, co jest sprzeczne z jej zapisami na temat prawa osób niepełnosprawnych do dokonywania wyboru w życiu społecznym na równi z innymi ludźmi. Konieczność zachowania możliwości wyboru między szkolnictwem włączającym a specjalnym podkreślili także dr hab. Grażyna Dryżałowska i prof. dr hab. Zenon Gajdzica, natomiast dr hab. Beata Jachimczak, zgadzając się w kwestii utrzymania szkół specjalnych, podkreśliła, że należy zmienić ich formułę. Biorąc pod uwagę sytuację osób niepełnosprawnych w mniejszych ośrodkach miejskich i na wsi, postulowała powołanie instytucji „mobilnych pedagogów specjalnych", którzy powinni być delegowani do pracy w powiatach „za dzieckiem". Taka forma działania daje każdemu uczniowi z niepełnosprawnością możliwość korzystania z edukacji w miejscu zamieszkania. Kończąc tę część debaty, dr hab. Grzegorz Szumski stwierdził, że systemy w pełni włączające są nierealne, gdyż są zbyt skomplikowane i drogie. Konieczne według niego jest wypracowanie właściwych wzorów funkcjonowania takich placówek oraz stworzenie silnego zespołu specjalistów w szkole. 
Drugi poddany pod dyskusję temat zazębiał się z problematyką edukacji włączającej, gdyż dotyczył kształcenia i kompetencji pedagogów specjalnych. Prof. dr hab. Iwona Chrzanowska, popierając wizję szkoły wspólnej dla wszystkich, zauważyła, że brakuje kadry, która potrafiłaby pracować w heterogenicznej grupie uczniów. Postulowała więc, by fakultatywny moduł 5 - przygotowanie w zakresie pedagogiki specjalnej ${ }^{1}$ - był obligatoryjny w kształceniu nauczycieli. Wskazała ponadto na korzyści płynące z organizowania studiów o profilu praktycznym, co pozwala wyposażyć absolwentów w większe kompetencje zawodowe. Zauważyła także, iż wprowadzenie egzaminów wstępnych w postaci sprawdzianu predyspozycji osobowościowych czyniłoby studia z zakresu pedagogiki specjalnej bardziej elitarnymi. Podobnego zdania był prof. dr hab. Zenon Gajdzica, który studia z zakresu pedagogiki specjalnej przygotowujące nauczycieli do pracy w edukacji inkluzyjnej widziałby jako nadbudowę dla studiów przedmiotowych, podczas gdy kształcenie kadry do pracy w osobami z głębszą i złożoną niepełnosprawnością odbywałoby się w ramach pełnych studiów na kierunku pedagogika specjalna. Prelegenci byli zgodni co do potrzeby wypracowania standardów kształcenia pedagogów specjalnych. Prof. dr hab. Amadeusz Krause stał na stanowisku, że dla pedagogiki specjalnej należy opracować moduł 1 (przygotowanie merytoryczne do nauczania pierwszego przedmiotu - prowadzenia zajęć) w standardach kształcenia nauczycieli oraz że błędne jest traktowanie fakultatywnego modułu 5 jako aktualnego standardu kształcenia pedagogów specjalnych.

Podczas gdy debata profesorska koncentrowała się wokół problemów praktyki edukacyjnej i kształcenia pedagogów specjalnych, druga debata, doktorska, dotyczyła habilitacji jako ścieżki rozwoju naukowego i awansu zawodowego w naukach społecznych. W dyskusji udział wzięli: dr Karol Bidziński (UJK Kielce), dr Marzena Buchnat (UAM Poznań), dr Katarzyna Ćwirynkało (UWM Olsztyn), dr Iwona Lindyberg (UG Gdańsk), dr Iwona Myśliwczyk (UWM Olsztyn), dr Dorota Prysak (UŚ KAtowice), dr Irena Ra-

${ }^{1}$ Standardy kształcenia przygotowującego do wykonywania zawodu nauczyciela zgodnie z Rozporządzeniem Ministra Nauki i Szkolnictwa Wyższego z dnia 17 stycznia 2012 r. przewidują obowiązkowe przygotowanie w zakresie: a) merytorycznym do nauczania pierwszego przedmiotu (prowadzenia zajęć) - moduł $1, b)$ psychologiczno-pedagogicznym - moduł 2, c) dydaktycznym - moduł 3; oraz przygotowanie fakultatywne: d) na nauczania kolejnego przedmiotu (prowadzenia zajeć) - moduł 4, e) w zakresie pedagogiki specjalnej - moduł 5 (Dz.U. z 2012 r., poz. 131). 
mik-Mażewska (US Szczecin), dr Agnieszka Wołowicz-Ruszkowska (APS Warszawa), dr Agnieszka Woynarowska (UG Gdańsk) i dr Renata Zubrzycka (UMCS Lublin).

Prowadząca debatę dr Dorota Krzemińska (UG Gdańsk) miała niełatwe zadanie moderowania dyskusji poruszającej wiele wątków, w tym trudności, wyzwania, ale i korzyści stojące przed habilitantem. Dr Karol Bidziński wskazał, że uprawianie nauki jako poszukiwanie prawdy w sytuacji narastającej presji obowiązku awansowania jest niezmiernie trudne i odbiera radość poszukiwań. Dr Marzena Buchnat zauważyła trudności pojawiające się w spełnianiu formalnych wymogów habilitacji wspólnych dla różnych dyscyplin naukowych oraz poruszyła problem ekonomiki punktów kierującej działaniami badaczy. Głos zabrała też dr Dorota Prysak, podkreślając ogromną rolę mentora, mistrza wspierającego habilitanta na trudnej drodze rozwoju naukowego. Natomiast dr Irena Ramik-Mażewska zaproponowała spojrzenie na habilitację jako ważny etap samoorozwoju i wewnętrznego dojrzewania badacza.

Pierwszy dzień obrad zakończyło zebranie założycielskie Polskiego Towarzystwa Pedagogów Specjalnych (PTPS) poprowadzone przez prof. dr. hab. Amadeusza Krause. Idea stowarzyszenia łączącego praktyków i akademików zrodziła się z potrzeby stworzenia silnego środowiska pedagogów specjalnych, które będzie skutecznie oddziaływać na organy władzy. Statut PTPS przewiduje funkcjonowanie stowarzyszenia poprzez 9-osobowy Zarząd Główny oraz Konwent Ekspertów. Konwent Ekspertów ma tworzyć 30-osobowa grupa czołowych specjalistów pedagogiki specjalnej z całej Polski wybieranych przez zarząd po to, by opiniować różne inicjatywy oraz projekty rządowe i społeczne dotyczące osób z niepełnosprawnością. Zamysł towarzystwa spotkał się z ogromnym poparciem uczestników konferencji. Podczas zebrania, oprócz złożenia deklaracji członkowskich, dokonano wyboru członków Zarządu Głównego, Komisji Rewizyjnej i Sądu Koleżeńskiego stowarzyszenia. Przewodniczącym PTPS został prof. dr hab. Amadeusz Krause, a na członków Zarządu spośród obecnych na sali powołano także prof. dr. hab. Zenona Gajdzicę, dr hab. Beatę Jachimczak oraz dr hab. Katarzynę Parys. Przewodniczący zapowiedział przekazanie dokumentów założycielskich do sądu w celu rejestracji stowarzyszenia, utworzenie strony internetowej oraz cykliczne zjazdy członków PTPS, m.in. przy okazji kolejnych Dyskursów Pedagogiki Specjalnej.

Drugi i trzeci dzień konferencji przebiegły w tradycyjnej formie obrad w sekcjach i obrad plenarnych. Uczestnicy konferencji obradowali w no- 
wym budynku Wydziału Nauk Społecznych Uniwersytetu Gdańskiego przy ul. Bażyńskiego w Gdańsku w ośmiu sekcjach tematycznych. Wystąpienia dotyczyły szerokiej problematyki z zakresu pedagogiki specjalnej, m.in. podmiotowości i autonomii osób z niepełnosprawnością, ich społecznego funkcjonowania $z$ uwzględnieniem tworzonych przez nie relacji interpersonalnych, tematyki rodziny i edukacji czy różnych form ich obecności w życiu społecznym. Wzorem lat ubiegłych jedna sekcja, prowadzona przez dr. hab. Sławomira Przybylińskiego, poświęcona była wątkom resocjalizacyjnym, a całość obrad naukowych wzbogaciły wystąpienia praktyków z placówek oświatowych, opiekuńczych i pozarządowych.

Obrady plenarne $\mathrm{w}$ dużej mierze koncentrowały się na społecznych aspektach życia osób z niepełnosprawnością. Prof. dr hab. Aniela Korzon zaproponowała inne spojrzenie na obecność w społeczeństwie osób niepełnosprawnych, zauważając swoistą "niesprawność” osób sprawnych wobec odmiennego funkcjonowania ludzi z tzw. "odchyleniem od normy”. Dr hab. Adam Mikrut przeanalizował zmiany w społecznej koncepcji niepełnosprawności, począwszy od definicji stworzonych przez Światową Organizację Zdrowia (WHO), po współczesną wizję niepełnosprawności w Konwencji o Prawach Osób Niepełnosprawnych. Wielokrotnie w czasie obrad pojawiały się kwestie równości społecznej, autonomii i wykluczenia osób niepełnosprawnych, m.in. w wystąpieniach dr hab. Bernadety Szczupał, dr. hab. Marcina Wlazło czy dr hab. Doroty Podgórskiej-Jachnik. Kilku prelegentów (prof. dr hab. Franciszek Wojciechowski, dr hab. Mariola Wolan-Nowakowska i in.) podjęło tematykę zatrudnienia osób niepełnosprawnych, w tym zagadnienia doradztwa zawodowego i zatrudnienia wspomaganego. W obradach plenarnych w mniejszym stopniu obecne były kwestie związane z rozwojem osób niepełnosprawnych. Prof. dr hab. Andrzej Twardowski zwrócił uwagę na rolę upełnomocnienia rodziców $\mathrm{w}$ procesie wczesnego wspomagania rozwoju, a dr hab. Anna Wojnarska - na znaczenie rozpoznawania ekspresji emocji w rozwoju społecznym osób z niepełnopoprawnością. Ciekawe i ważne doniesienia z badań na temat przemocy doświadczanej przez osoby z niepełnosprawnością intelektualną przedstawiła dr hab. Agnieszka Żyta, pokazując możliwości i korzyści płynące $\mathrm{z}$ badań interdyscyplinarnych $\mathrm{w}$ pedagogice specjalnej.

Oprócz obrad organizatorzy zapewnili uczestnikom czas wolny i możliwość zwiedzenia Gdańska oraz skorzystania z uroków pobliskiej plaży. Było to okazją nie tylko do odpoczynku, ale i do wielu rozmów, integracji środowiska, wymiany doświadczeń i nawiązania współpracy. Tegoroczne 
Dyskursy Pedagogiki Specjalnej zaowocowały bogatą prezentacją współczesnej myśli pedagogiki specjalnej. Jak zwykle pozostawią one ślad w postaci mającej ukazać się publikacji, ale to nie wszystko. Powołanie do istnienia Polskiego Towarzystwa Pedagogów Specjalnych daje nadzieję na bardziej znaczący udział pedagogów specjalnych w podejmowaniu ważnych decyzji dotyczących osób z niepełnosprawnością w naszym kraju. 